\title{
Colouring inside what lines? Interference of the urban growth boundary and the political-administrative border of Brussels
}

Kobe Boussauw****, Georges Allaert*, Frank Witlox**

* Civil Engineering Department, Center for Mobility and Spatial Planning, Ghent University, Vrijdagmarkt 10/301, B-9000 Gent, Belgium

Tel.: +3293313250 - Fax. +3292645489

E-mail: kobe.boussauw@ugent.be,georges.allaert@ugent.be

** Geography Department, Ghent University, Krijgslaan 281/S8, B-9000 Gent, Belgium

Tel.: +329264 4555 - Fax.: +3292644985

E-mail: kobe.boussauw@ugent.be,frank.witlox@ugent.be

\begin{abstract}
This paper discusses the relationship between the political-administrative border and the urban growth boundary around Brussels, the Belgian capital. Our hypothesis is that the interests of the various regions and language groups in Belgium interfere strongly with urban planning policies, implying that the administrative border of the Brussels-Capital Region operates in reality as an unintended urban growth boundary. Based on demographics, commuter data and property market features, we argue that this situation may cause excessive urban compaction of the Brussels-Capital Region, while spillover effects to municipalities that are rather distant from Brussels may result in undesired forms of suburbanization and long distance commuting.
\end{abstract}

\section{Keywords}

urban containment policy

urban growth boundary

language border 
Brussels

Belgium

\section{Introduction}

The modern version of the urban planning practice of demarcating urban areas has been in use for several decades. In the academic literature, such strategies are typically referred to as urban containment policies (Dawkins and Nelson, 2002), and are, in most cases, implemented in the form of an urban growth boundary (UGB). According to the American literature, a contemporary version of the UGB was first introduced in 1958 in the city of Lexington (Kentucky), where a green belt around the city was established with the primary aim of preserving the surrounding characteristic horse farming landscape (Ding et al., 1999). In 1973, the state of Oregon voted a law that forced all cities to apply UGB's in their spatial development plans, after which the city of Portland implemented this duty in 1977 by establishing its own UGB, based on a broad range of objectives which were only to a small extent inspired by issues of landscape preservation (Song and Knaap, 2004). This development induced an evolution whereby over the next decade the demarcation of urban areas became a common practice in many American states, including Oregon and Washington where the establishment of UGB's is required by state law. However, in a European context, forms of urban containment policy have in fact emerged even earlier. The ideas of Ebenezer Howard, who was around 1900 the founder of the idea of the 'garden city', gave in 1935 rise to the creation of the socalled Metropolitan Green Belt around London. During the twentieth century, many European cities and regions introduced a form of urban demarcation (with England, the Netherlands and Switzerland as representative examples), while also Japan and South Korea (Jun, 2004) started applying a form of urban demarcation as a planning instrument (Millward, 2006). But in fact, the practice of spatial delimitation of cities goes a lot further in history. Many medieval towns in Europe continued well into the nineteenth century to grow only inside their ramparts, where safety and the presence of toll gates were important reasons to stay living inside the city walls.

Five main arguments are generally put forward to advocate the practice of delineating urban areas. These are quite diverse, but have in common that they are 
aiming to internalize the social costs that are caused by uncontrolled urban expansion and sprawl. Millward (2006) presents the protection of open space around the cities as one of the original reasons for limiting the expansion of the urban area. Given the fact that the aesthetic, recreational and ecological value of the landscape as a public good does not manifest itself in the monetary appreciation of the land, it is the responsibility of the government to ensure its preservation. Obviously, this argument is more important in rather urbanized areas than in cities that are embedded in a sparsely populated region where a lot of space remains available for agriculture, nature and recreation. A second traditional argument is the disproportionate additional cost that is caused by the supply of urban services to sprawling residential developments. As services such as utility lines, construction and maintenance of road infrastructure, public transport and mail delivery are usually provided at average cost per capita - and thus not at marginal cost per additional dwelling, uncontrolled remote development gradually raises these costs for all residents of the city or region (Ding et al., 1999). Due to high marginal costs, some utilities, such as wastewater treatment, may even lack at all in remote areas, resulting in an external social cost which does not manifest itself in monetary form, but in the form of excessive pollution. According to Brueckner (2007), another important external cost of sprawl is to be found in the excessive development of commuting by car, which eventually leads to major congestion problems and unforeseen time losses in commuting, while the nuisance caused by traffic (including poor air quality) is high in the core city, and potential patronage of public transport is small because of the relatively low population density.

A fourth argument for limiting uncontrolled development can be found in the idea that residents of compact cities are able to keep their ecological footprint a lot smaller than people living in peripheral suburban areas. The reason is that residents of dense cities tend to cause less car traffic and live in smaller dwellings, so they are expected to consume less energy (and thus cause fewer emissions) for their transport needs and the heating of their homes (Burby et al., 2001). Besides the fact that residents of a compact city get by with less energy, also the potential to further reduce a resident's footprint is greater in the city than in a suburban area (Boussauw et al., 2011). 
A fifth argument, finally, is the assumed role of compact development in devising an equal urban system, with a good balance between homes, jobs and services, a high degree of internal accessibility, and reduced social segregation as a result (Nelson et al., 2004). Targets aimed at combating the deterioration of historical city centres are part of this argument: by limiting spatial expansion, the demand for housing in the city will be kept at a high level, inducing renovation activities.

On the effectiveness of an UGB as a tool for achieving the set objectives, and on the question whether or not some supposed unpopular consequences of the demarcation of cities (such as rising real estate prices and smaller houses) are justified, little convincing empirical evidence has been published. Within the urban-economics literature a form of consensus has even emerged on the fact that fiscal measures (such as charging the marginal cost of services to builders of new homes, or the introduction of road pricing) would be more effective than demarcating the urban area. However, in reality it is observed that UGB's are particularly popular in spatial planning practice. We conclude that this instrument, which is called "blunt" by Brueckner (2000), is often considered useful by policy makers. In the next section we show that the implementation form, as well as the geographical, economic, political and legal context in which an UGB is implemented, may determine to a large extent its impact.

Next, we assess practices and effects of urban containment in the area of Brussels, the Belgian capital. Brussels is a highly interesting case since it is a politically independent city-region within the federal state of Belgium, implying that its urban development is seriously influenced by spatial policies of the neighbouring regions. We will show that urban densification occurs through an unintentional, highly specific interference of a political-administrative border and an urban growth boundary, while spillover effects may have undesired effects in terms of periurbanization and associated long distance commuting.

\section{Expected effects of an UGB}

In short, through land supply restrictions an UGB is expected to lead to infill development, and, through conversion of the existing building stock, to a gradual increase of residential density (Brueckner, 2000). The presumed positive effects on 
society are to be found in the preservation of the open space outside the UGB, in the relatively low cost of public services and utilities, in the reduced overall traffic volume (which is associated with mitigated congestion costs), and in a relatively high level of patronage supply and thus support for an efficient public transport network. The presumed negative consequences for (new) residents of the urban area are an increase in property price levels and the shrinking size of an average residential unit. Although the alleged benefits are consistently adduced by concerned policymakers and advocates of compact development, and the alleged disadvantages are used as an argument by the opponents of strict spatial policies, in practice it appears very difficult to assess the effects of the implementation of an UGB in an objective way. In Portland, where one of the oldest UGB's of the US is in force, Jun (2004) does not find any significant densification within the UGB, while the neighbouring municipalities, that have not adopted an UGB grow faster than Portland itself. The average travel time in the commute grew faster inside than outside the UGB. Part of the increase in travel time may be due to the spillover effect, meaning that suburbanization occurs on average farther from the city centre (i.e. in the neighbouring municipalities), compared to the period before the establishment of the UGB, while a large part of the suburban commute is continuously directed towards Portland.

In an international comparative study, Dawkins and Nelson (2002) found that land prices within an UGB indeed increase faster than outside the UGB, but that this is not necessarily the case for the prices of houses. The price evolution in the housing market depends, among other factors, on how the UGB is implemented, and in particular on the presence or absence of any policy aimed at urban compaction through redevelopment. However, in case the total number of homes inside the UGB is intentionally limited, as is done in several cities in California, rapid price increases in the housing market are observed (Dawkins and Nelson, 2002). In Portland, Jun (2006) reports similar findings: inside Portland's UGB housing prices do not necessarily rise faster than outside the UGB, which is partly attributable to the spillover effects to neighbouring municipalities where less growth restrictions apply. Empirical studies, however, continue to face serious difficulties in isolating effects caused by the presence of an UGB. It is almost impossible to evaluate the evolution 
of transport parameters, such as average travel time and distance, the level of congestion or the modal share of public transport, in relation to the presence or absence of an UGB, since other elements such as the historical structure and the economic performance of the city are preponderant in the short term. Rodriguez et al. (2006) even suggest that residents of cities that are bounded by an UGB actually may travel longer distances by car than residents of non-bounded cities, which is contrary to the hypotheses that advocate urban compaction. Also, comparing real estate prices between cities with and cities without an UGB is a tricky undertaking: there may be a possible link between the decent economic performance of a city, which is reflected in high property prices and a lot of construction activity, and the presence of social support for the introduction of an UGB (O'Neill et al., 2011). Another difficulty is the particular inertia of property markets, which implies that significant effects can only be expected in the very long term.

It is fair to say that the expectations raised by UGB's do not have their origin in recent empirical studies, but spring from urban-economics theory (based on the bidrent theory of Alonso-Muth-Mills) and observations of the historical development of cities that are demarcated in a natural way. Urban-economics theory teaches us that by restricting the supply of future construction land, land prices will inevitably rise over time, with a higher building density as a long-term result. A number of examples of historical cities with a natural boundary, because of their location on a peninsula (e.g. New York, San Francisco, or Stockholm) or because of being surrounded by a flood-prone area (e.g. Amsterdam), show that the presence of spatial constraints actually leads to higher densities compared to similar cities without these geomorphological constraints .

\section{Forms of implementation of UGB's}

UGB's have been implemented in various ways. In most cases, an UGB delineates an area inside which open-space land use (such as agriculture or nature) can be converted into construction land. The boundary of the area is revised whenever a political consensus exists on the necessity to do this. Outside the boundary, the designation of additional construction land can only be granted in exceptional cases (Knaap, 1985). 
However, varying degrees of regulation can be discerned. In the least stringent case, an UGB is defined in a rather spacious way, including enough non-built-up land to meet the demand within the planning horizon (which is usually about 10 to 20 years) (Knaap and Hopkins, 2001), after which the boundary may again be expanded. Such a strategy will prevent leap-frog development and the deterioration of the open space belt around the city, but it will hardly result in any compaction of the core city. This type of policy is common in Canada (Millward, 2006) and in some US states. A more restrictive policy may define the development zone in a narrower sense, while a parallel renovation strategy can be formulated with the aim of restructuring old neighbourhoods and brownfields in order to obtain higher average housing densities. Another variant may contain an absolute upper limit to the number of houses that should be built within the demarcation line. The latest version of an UGB is in effect in several cities in California (Dawkins and Nelson, 2002).

Also with respect to the area outside the demarcation line, several gradations can be distinguished. A non-restrictive policy could for example allow that new dwellings are built in the open space, as long as the density remains very low and the homeowners are responsible for their own water supply and sanitation. This type of policy is applied in many American cities, such as Atlanta (ARC, 2011). A slightly more restrictive policy could allow only the already designated construction areas outside the demarcation line to be developed, or could stipulate that only existing buildings (e.g. farms) may be converted into dwellings, or that new construction is only allowed if it is immediately adjacent to an existing settlement with utilities available. This kind of policy is found in the draft Dutch Fifth Spatial Planning Memorandum. In this policy plan, the national government is responsible for determining so-called "red contours" around the urban areas. Inside these contours, municipalities would be free to make changes in land designation, while outside the contours a restrictive policy would be applicable under the control of a higher authority (Priemus, 1998). Although the Fifth Memorandum was never adopted by the Cabinet, and has therefore never been in force, the proposed contour policy is still implemented within the planning competences of some provincial authorities in The Netherlands (Zonneveld, 2005). The particular strategy of demarcating urban areas that is in force in Flanders (Belgium) (RSV, 1997/2004) was developed in parallel with the Fifth 
Memorandum. A further tightening may contain regulations that forbid any additional construction area to be designated outside the UGB, or even that current construction land outside the UGB is to be converted into protected open space area. These forms of policy apply in Great-Britain, Japan and Switzerland (Gennaio et al., 2009; Millward, 2006).

Regardless of urban boundaries, there are cities that are for political reasons delineated by an administrative boundary, which in practice operates as a development boundary. Most examples, such as Singapore, Hong Kong, Monaco and Gibraltar are enclaves or city-states where the administrative boundary coincides with a geomorphological boundary. But there are also cases imaginable where the same phenomenon occurs despite the absence of any form of geomorphological boundary. In what follows, we will elaborate the case of Brussels, the Belgian capital, which has been a de facto separate region within the federal structure of Belgium since 1980, and forms, geographically speaking, an enclave within the much larger Flemish Region (Fig. 1). Although the Brussels Region is separated from the Flemish Region by an administrative border, the Flemish government has recently introduced an urban development boundary that is limiting the expansion and development of the outskirts of Brussels in the territory of the Flemish Region.

\section{Brussels and Flanders: political, administrative and urban context}

Since 1970, a consecutive series of constitutional reforms has transformed Belgium from a unitary state into a federal state, which formally consists of three (territorial) regions (the Flemish Region, the Walloon Region and the Brussels-Capital Region) and three (language) communities (the Flemish (Dutch speaking) Community, the French Community and the German-speaking Community) (Deschouwer, 2006). Over the past decades, many of the competences that were originally assigned to the federal government have been split up and assigned to the regions and communities. In general, all territorial policies such as environment, mobility, employment, housing and urban and regional planning are assigned to the governments of the three regions, and personal matters such as education, culture and welfare, are assigned to the governments of the communities. Since the latest constitutional reform of 2001- 
2003, the major remaining federal competences are located in the area of social security, taxation, defence and foreign affairs.

In 1962, even before the first constitutional reform, the so-called language borders were set which define the official linguistic regions. Today, this means that the Brussels-Capital Region is officially bilingual (French-Dutch), that the Flemish Region is officially Dutch-speaking, and that the Walloon Region contains a Frenchspeaking and a (small) German-speaking area. A number of municipalities along the language border are required to supply services in a language other than the official language of the region they belong to. These municipalities are called "facilitating municipalities" (Oosterlynck, 2010).

The Brussels-Capital Region (BCR) is very different from the other two regions, because it consists of only one metropolitan area covering no more than 161 square kilometres, a population of over 1.1 million and thus a gross population density of about 7,000 inhabitants per square kilometre. The Flemish Region $\left(13,500 \mathrm{~km}^{2}\right.$ and 6.3 million inhabitants) and the Walloon Region $\left(16,800 \mathrm{~km}^{2}\right.$ and 3.5 million inhabitants), in contrast, comprise dozens of cities and hundreds of municipalities. Administratively spoken, BCR consists of nineteen municipalities, which are headed by a regional government. Because of the official bilingualism, also both the Flemish and French Communities have an active role in BCR. In practice, today the Dutchspeaking form a small minority in all municipalities of BCR, comprising, depending on the source, about 5\% (Lambert and Lohlé-Tart, 2010, p. 1) to 16\% (Janssens, 2007, p. 30) of the population. This evolution finds its origin largely in the cosmopolitan character of Brussels, which has made the population gap, that was caused in recent decades by suburbanizing Dutch- and French-speaking inhabitants of Brussels, filling up quickly by foreign immigrants, many of whom know French but no Dutch. With the development of Brussels as the capital of the European Union, the international appeal of the city greatly increased, which is reflected in rapid growth of the population and national and international migration flows, as well as soaring real estate prices and development. The phenomenon of urban flight in the post-war period, which has led to the decay of many inner cities in Belgium, has in recent decades transformed into a cascade system where (foreign but also Belgian) immigrants initially settle in major cities, and especially in Brussels. In this 
way, they fill the gap that was caused by suburbanization towards the surrounding commuter areas. Over time, e.g. when a stable professional and family life is achieved, a part of this immigrant population is itself suburbanizing (Van Criekingen, 2008). This phenomenon leads to additional pressure on the property market, both inside BCR as in the suburban areas around Brussels, which are in geographical terms mainly located in the Flemish Region.

By the Flemish cultural movement, the migration flows from Brussels are frowned upon, raising suspicion for 'Frenchification' of the Flemish neighbouring municipalities of BCR. Consequently, the Flemish regional government invests largely in support of Dutch-language education and cultural activities in these suburban communities. The municipalities themselves have a long tradition in their housing policy, only sparingly allowing new homes to be built, and continuously seeking ways to attract Dutch-speaking residents (Meert, 1993, p. 110). These mechanisms have been successful to some extent, and have limited population growth, especially regarding the non-Flemish. However, the fact remains that a significant portion of the suburbanization flow from BCR ends up in the surrounding Flemish province of Vlaams-Brabant ("Flemish Brabant"), rather than in the smaller Walloon province that is nearest to BCR (Brabant wallonne or "Walloon Brabant"), as illustrated in Table 1. Given the de facto predominantly French-speaking character of BCR, we assume that the Frenchification of the Flemish periphery around Brussels is uninterruptedly continuing (Valasek, 1990), and has induced at least some of the recent and less recent political controversy surrounding the further reform of the Belgian federal state (Willemyns, 2002).

Table 1. Migration flows between BCR and the provinces of Vlaams-Brabant (Flanders) and Brabant wallon (Wallonia) in 2006

\begin{tabular}{|c|c|c|c|}
\hline origin $\backslash$ destination & Brussels-Capital Region & Vlaams-Brabant & Brabant wallon \\
\hline Brussels-Capital Region & 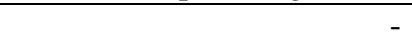 & 14639 & 6437 \\
\hline Vlaams-Brabant & 7510 & - & 2263 \\
\hline Brabant wallon & 3687 & 1156 & - \\
\hline
\end{tabular}

A specific element in the history of Belgian urbanization is the institutionalized commute, which has been made possible by the advent of the railways, and has been 
accompanied with explicit anti-urban policies. Although anti-urban ideologies also occurred elsewhere in Europe (Marchand and Cavin, 2007), in Belgium this phenomenon has explicitly materialized in the construction of a very extensive railway network during the nineteenth century. In combination with cheap season tickets for employees, this has laid the foundation for an urban structure based on cities as employment centres, and rural areas as residential environment. So, employees could be part of the new industrial society, without necessarily having to move to the city where they could fall prey to social movements such as socialism and fall off Christian values and norms (Dickinson, 1957; De Decker, 2011). However, the spatial aspect of the implicitly existing restrictive housing policy at municipal level was only recently included by the Flemish government in its plans to set up an - so far non-existent - UGB around Brussels. Since the Brussels agglomeration exceeds the administrative border of BCR, it is logical that a UGB is located in the Flemish Region. Our hypothesis is that the UGB of the Flemish government is however incompatible with the urban planning objectives (the organization of urban development on the basis of controlled densification) of a metropolitan area such as Brussels, and that the conflicting political interests of the Flemish Region and BCR have led to a situation where the administrative border is de facto operating as an urban growth boundary. Using data on demographics, commuting, and the property market, we will demonstrate this thesis in the following sections.

\section{Spatial policy in Belgium}

Through the first (federal) law on urban planning in 1962, for the entire Belgian territory zoning plans (in Dutch: "gewestplannen", and in French: "plans de secteur") have been developed, which have designated in most municipalities rather large areas of undeveloped construction land, granting the possibility to the owners of the land in these zones to apply for a building permit (Albrechts, 1999). The centralist way in which the activity of drafting these plans was coordinated strongly reminds of the French approach, while the area covering nature of the zoning plans rather originates from Dutch planning practice (Oxley et al., 2009). Depending on the local context, quite a few of these zoning plans are considered to have been rather 
generously in allocating residential zones. These plans did not always contribute to the qualitative development of existing and new residential areas, and especially where rather remote, rural municipalities were involved, the plans may have accelerated processes of suburbanization and desurbanization (Albrechts 1999; Lepers and Morelle, 2008).

As a consequence of both the constitutional reform and a new, more quality-oriented planning approach, urban and regional planning policy in the Flemish Region, in $\mathrm{BCR}$, and in the Walloon Region, is today based on three different policy plans, that were developed and approved by three individual governments. The Spatial Structure Plan for Flanders (in Dutch, Ruimtelijk Structuurplan Vlaanderen, or RSV) (RSV, 1997), which may be considered as the first full-fledged spatial policy plan for the Flemish Region, decided in 1997 to strengthen the dichotomy between urban and outlying areas. The RSV presents "deconcentrated clustering" as one of the main principles for steering spatial developments (Albrechts et al., 2003; Scheers, 2006). "Clustering" means selectively concentrating the growth of living, working and other social functions in cities and centres, while "deconcentrated" means accounting for the existing (deconcentrated) development pattern and the spread distribution of dynamic functions throughout Flanders. The protection of open space and the revitalization of the urban fabric are clearly paramount. By pursuing a spatial concentration of development in precisely those areas that already possess a significant density, fragmentation of the (open) space is supposed to be combated, while existing facilities and infrastructure will be used in a more efficient and more sustainable way.

The most important instrument that is proposed to pursue these objectives is the demarcation of the urban areas through UGB's, meaning that a line is drawn around those areas that should be reserved for the development of new highly dynamic activities (Leinfelder and Allaert, 2010). Additional supply of residential and industrial land is provided in these urban areas (the Brussels agglomeration is considered one of these), and in new residential developments a minimum density of on average 25 dwellings per hectare (within a spatially coherent entity) is aimed for. Apart from the demarcation of the urban areas, the RSV also proposes a delineation of the main natural and agricultural areas. 
The first version of the RSV (1997) suggests that the areas inside the future UGB's should receive $60 \%$ of additional homes in the Flemish Region, which means that still $40 \%$ of new housing could be built on existing designated construction land outside the UGB's. Besides, the tools provided to achieve this goal are rather weak: the promotion of residential development is done by designating additional construction land for housing inside the UGB's, but there is no tool to slow down residential development outside the UGB's (e.g. by suppressing yet undeveloped construction land and converting it into protected open space). The revised version of the RSV (2004) has even further adjusted the original target of $60 \%$ of new housing to be built within the UGB's downwards to (in practice) 54\% (Voets et al., 2010, p. 39). This objective is rather loose, and may even not be significantly different from a development that would have been based solely on the old zoning plans, as may be illustrated by Weitz and Moore (1998) who argue that compact development implies that at least $70 \%$ of new housing should be built within some kind of UGB.

In BCR, the RSV is not in force. The second version of the overarching spatial policy plan for Brussels (the Regional Development Plan (GewOP/PRD, 2002)) is in fact not a regional, but rather an urban development plan. Compared with the RSV, the GewOP/PRD is much clearer in relation to the regulation of density and land use mix. As the entire BCR may be considered as urban area, the GewOP/PRD does not propose an UGB to demarcate the city, neither does it include a general objective of increasing residential density.

The third plan, for the Walloon Region, is called the Schéma de Développement de l'Espace Régional (SDER). Unlike the RSV, this policy plan is primarily a conceptual framework based on principles of sustainable spatial development, without introducing new planning tools (such as the demarcation of urban areas) (Lepers and Morelle, 2008). From a national point of view, Vandermotten et al. (2006) warn against the drawbacks of such a fragmented spatial policy, where the lack of an overarching vision may turn to the detriment of the urban areas, and of Brussels in particular.

In the design stage of the RSV in 1996, fifteen Flemish municipalities were proposed to be at least partially part of the "metropolitan area of the Flemish periphery around Brussels." It was suggested to initiate a wide consultation process that would lead to 
a precise demarcation (by means of an UGB), and to consequently implement a policy of urbanization in this delineated urban area. The public review process of the RSV, however, yielded a flood of objections to this approach, and in the final plan (approved in 1997) it was determined that this specific urban area around Brussels should get an own development perspective, which would be less ambitious in terms of growth compared to the other urban areas in Flanders. The area was renamed "Flemish urban area around Brussels" (VSGB), while quantitative targets for the development of additional dwellings and business estates were reduced, and the emphasis was now strongly placed on the protection of the open space (RSV, 1997, p. 372).

The consultation process aimed to lead to the eventual demarcation of the area was formally launched in November 2004, and resulted in December 2010 in a proposal that was ratified by the Flemish government, after which a public review process began (in the spring of 2011). During the process, the name of the region was again changed into "Flemish strategic area around Brussels", with the same abbreviation VSGB but omitting the urban connotation. The UGB that was finally adopted by the Flemish government in December 2011 is shown in Fig. 1.

It is tempting to blame the politicians, civil servants and consultants who were involved in the plan for having dealt in an inconsistent way with the original objectives of the demarcation of the urban areas, as stated in the 1997 RSV. However, it is fair to say that the inhabitants of the Flemish periphery around Brussels clearly have shown an anti-urban attitude and have succeeded in adjusting the plan accordingly. Perhaps this observation fits in the context of the historical anti-urban attitudes that we have perceived in Belgium's past, as explained in $§ 4$, although today we see no longer aversions against "subversive movements" (like socialism), but rather against the expansion of a multicultural society which is very urban in nature (De Maesschalck, 2011).

\section{Demographic trends in Brussels and the surrounding commuter area}

To understand the demographic evolution of BCR and the surrounding region, we give the population figures for the periods 1990-1995 and 1995-2010 for various 
geographical classes (Statistics Belgium, 2011a). The period before 1995 was characterized by a form of suburbanization that resulted in shrinkage of the Brussels population. In the period after 1995, BCR regained its international appeal, which was more than compensating the demographic deficit of the years before. For the region around Brussels, we consider five different classes. The first class consists of the nineteen municipalities that are commonly known to form together the Flemish periphery around Brussels. The second class consists of the Brussels urban agglomeration, as defined by Luyten and Van Hecke (2007). The third class consists of the suburban area around Brussels, and the fourth class are the commuter areas around Brussels, again as defined by Luyten and Van Hecke (2007). In the last three classes, we consider the evolution of the Flemish and Walloon municipalities separately. The used classification can be found in Fig. 1 while the corresponding figures are shown in Table 2.

Since the method of Luyten and Van Hecke (2007) assigns each municipality in both the suburban area and the commuter area to only one urban agglomeration, we present in Fig. 2 also the Brussels "employment basin", consisting of the municipalities that are assigned to the suburban area and the commuter area of BCR (and consequently do not belong to the employment basin of, for example, Leuven or Mechelen).

Fig. 1. Administrative borders, proposed urban growth boundary and spatial classes of the region around Brussels 


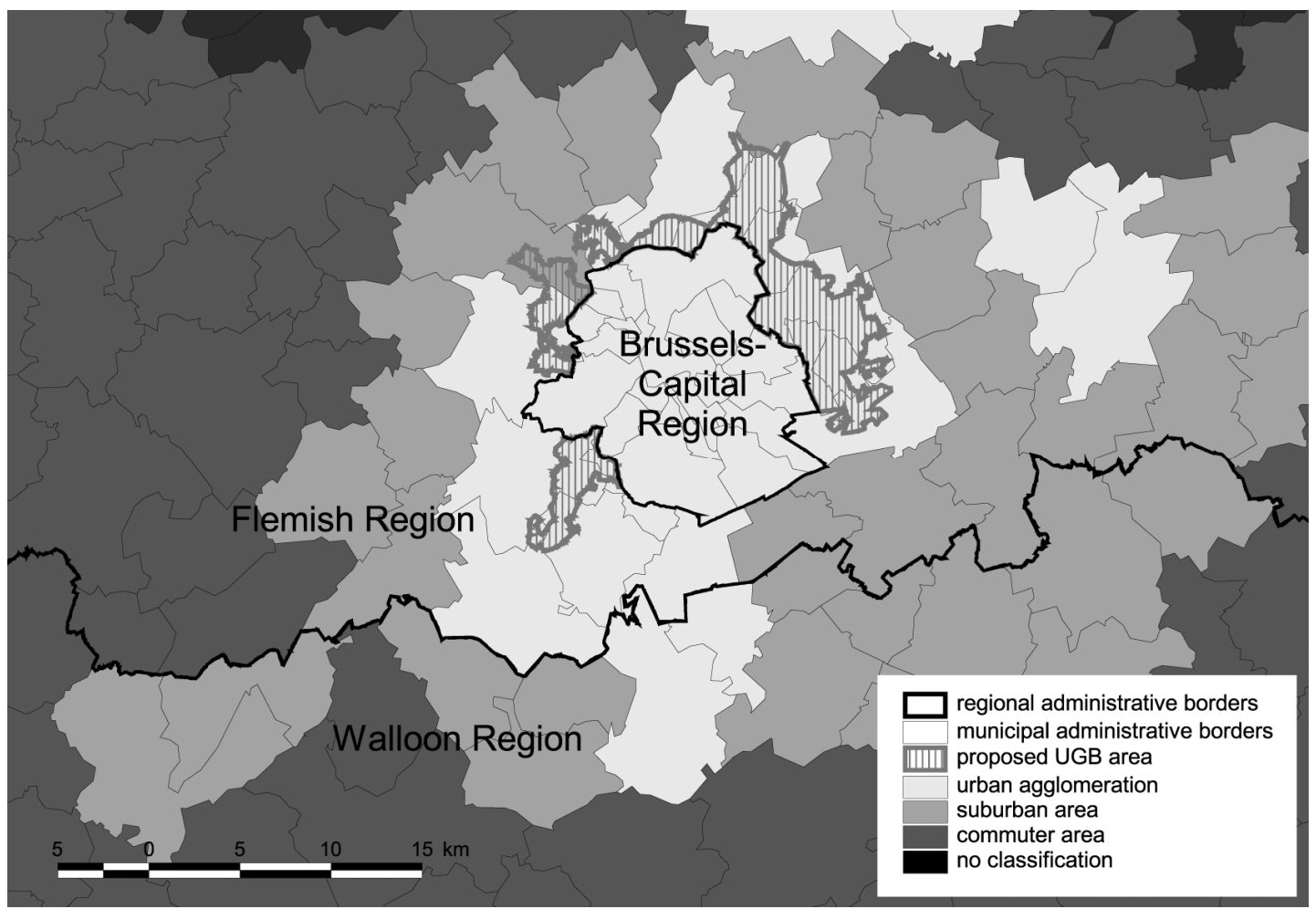

Fig. 2. BCR's employment basin in relation to the other regional employment centres

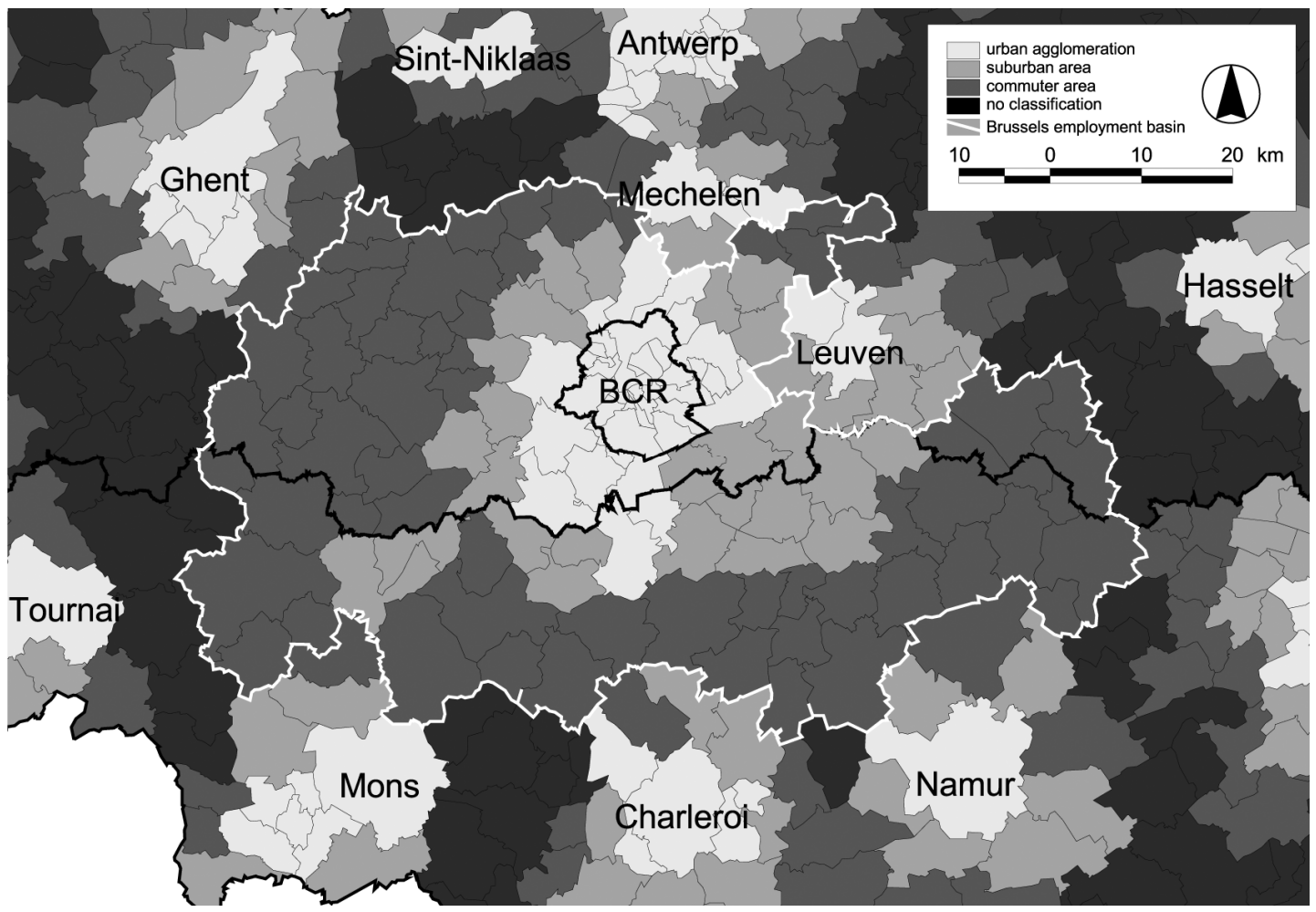


Fig. 3. Evolution of the population in BCR's employment basin and its surroundings, 1995-2010, by municipality

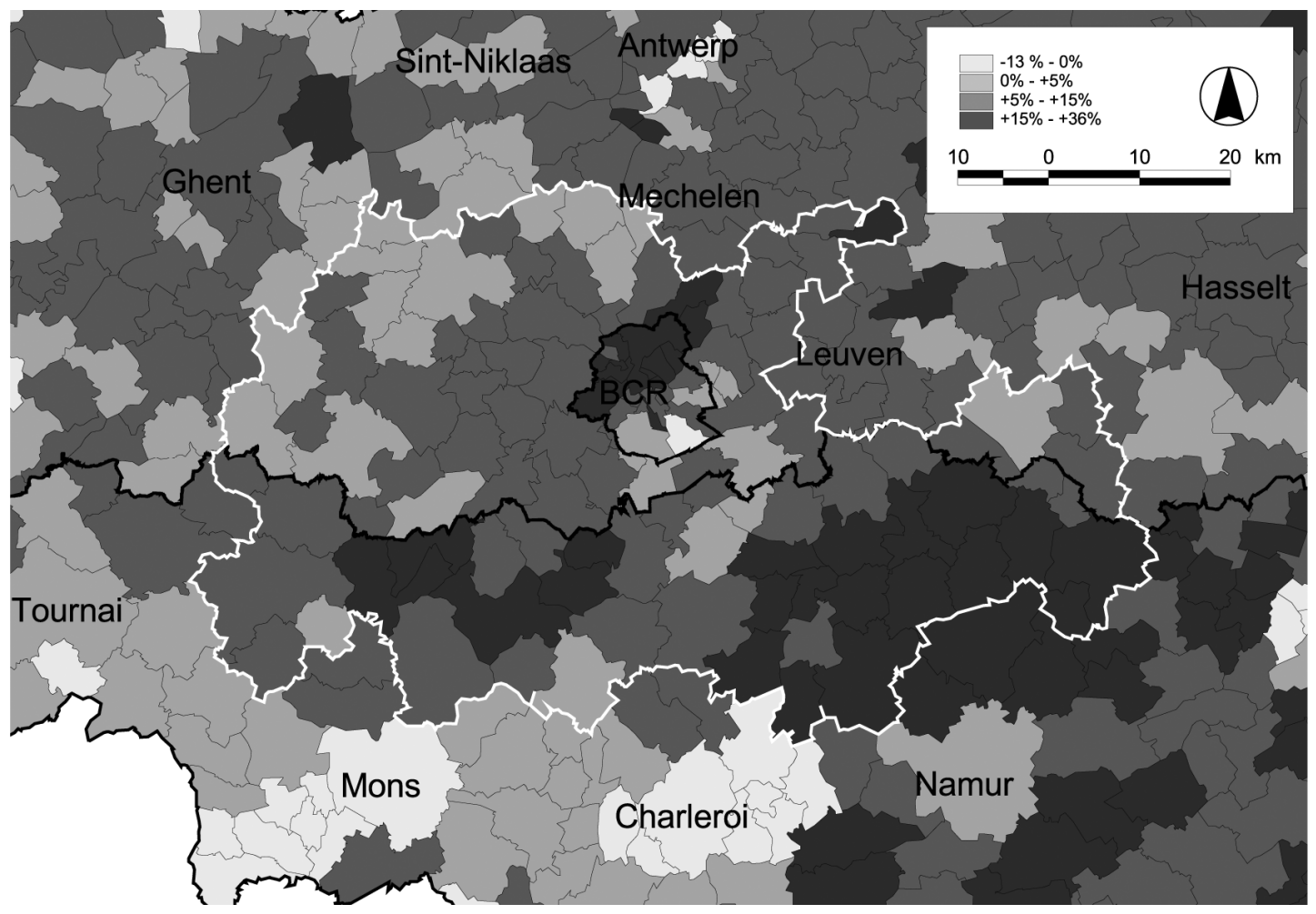

Table 2. Evolution of the population in BCR and its surroundings

\begin{tabular}{|l|r|r|r|r|r|}
\hline & \multicolumn{1}{|c|}{1990} & \multicolumn{1}{|c|}{1995} & \multicolumn{1}{|c|}{2010} & $1990-1995$ & $1995-2010$ \\
\hline Brussels-Capital Region & 964385 & 951580 & 1089538 & $-1.3 \%$ & $+14.5 \%$ \\
\hline Flemish Region & 5739736 & 5866106 & 6251983 & $+2.2 \%$ & $+6.6 \%$ \\
\hline Walloon Region & 3243661 & 3312888 & 3498384 & $+2.1 \%$ & $+5.6 \%$ \\
\hline Belgium & 9947782 & 10130574 & 10839905 & $+1.8 \%$ & $+7.0 \%$ \\
\hline Flemish periphery around Brussels & 363541 & 373274 & 403833 & $+2.7 \%$ & $+8.2 \%$ \\
\hline Urban agglomeration of Brussels & 1331003 & 1328216 & 1498593 & $-0.2 \%$ & $+12.8 \%$ \\
\hline Urban agglomeration of Brussels - Flemish & 307205 & 314576 & 341154 & $+2.4 \%$ & $+8.4 \%$ \\
\hline Urban agglomeration of Brussels - Walloon & 59413 & 62060 & 67901 & $+4.5 \%$ & $+9.4 \%$ \\
\hline Suburban area of Brussels & 329826 & 348381 & 384854 & $+5.6 \%$ & $+10.5 \%$ \\
\hline Suburban area Brussels - Flemish & 165557 & 172679 & 186912 & $+4.3 \%$ & $+8.2 \%$ \\
\hline Suburban area Brussels - Walloon & 164269 & 175702 & 197942 & $+7.0 \%$ & $+12.7 \%$ \\
\hline Commuter area of Brussels & 768808 & 791714 & 859726 & $+3.0 \%$ & $+8.6 \%$ \\
\hline Commuter area of Brussels - Flemish & 506150 & 514899 & 544951 & $+1.7 \%$ & $+5.8 \%$ \\
\hline Commuter area of Brussels - Walloon & 262658 & 276815 & 314775 & $+5.4 \%$ & $+13.7 \%$ \\
\hline
\end{tabular}

Table 2 and Fig. 3 illustrate the outlined phenomenon. The Flemish periphery around Brussels grows much slower than BCR itself, while the Walloon municipalities that are part of the suburban and commuter areas around Brussels grow almost as fast as 
BCR itself. ${ }^{1}$ Since the UGB was not yet in force in 2010, it seems as though the administrative border of BCR operates in practice as an unintended UGB, inside which a rapid and systematic process of urban compaction occurs. In addition, we also notice spillover effects towards the Walloon municipalities that are part of the suburban and commuter areas around BCR. The implicit policy of the municipalities in the Flemish periphery to slow down growth and to discourage particularly nonDutch speakers to move into these municipalities did not only result in densification of BCR, but also in a form of peri-urbanization in that part of the Walloon Region that is located relatively close to Brussels. Part of the imbalance of internal migration flows between the French-speaking and the Dutch-speaking parts of Belgium may also be explained by legal language issues. A French speaking resident of Brussels will be inclined to limit his residential location choice to those municipalities where he will find francophone facilities, restricting himself to the municipalities in Brussels and Wallonia, as well as the few municipalities in the Flemish Region that offer these francophone facilities as well.

This is supported by data on the commute (Table 3) (Statistics Belgium, 2011b) and on the property market (Tables 4, 5 and 6) (Statistics Belgium, 2011c). For commuter data, we rely on the decennial censuses. These censuses took place in 1991 and 2001, and may thus not be compared with the periods over which we have observed population figures (1990-1995 and 1995-2010). Moreover, commuter data from 1991 and 2001 may not simply be compared because of important methodological differences regarding the collection. However, through normalization of the data, we may have a good idea of the increase in commuter flows. As expected, the strongest growth in commuter flows directed towards BCR are observed in the Walloon suburban areas and, especially in the Walloon commuter areas. Although a major new economic development centre around OttigniesLouvain-la-Neuve, including activities induced by the presence of the Université Catholique de Louvain, may have alleviated the growth of the commute from Wallonia to Brussels, Table 3 indicates that this influence must be limited.

${ }^{1}$ The population in the Walloon part of the Brussels urban agglomeration does not seem to grow much faster than the population in the Flemish part. However, we will not discuss this observation 
In Table 4, we have presented the prices of construction land. Although Van Nuffel (2005, p. 122) indicates that because of large regional differences in housing quality, prices of houses are generally not representative of the value of the studied site, for the sake of completeness we have complemented this table with an overview of the evolution of prices of regular houses (Table 5). At a first glance, we observe the expected centripetally downward trend of price levels when moving away from BCR, which is in line with the Alonso-Muth-Mills model. Regarding price evolution, regional patterns are less evident, which is typical of the high degree of complexity that underlies real estate prices.

Table 3. Evolution of the number of commuters towards BCR

\begin{tabular}{|l|r|r|r|}
\hline & \multicolumn{1}{|l|}{1991} & \multicolumn{1}{c|}{$\begin{array}{c}\text { 1991-2001 (normalized with } \\
\text { basis: Belgium in 1991) }\end{array}$} \\
\hline Brussels-Capital Region & 240346 & 176780 & $-13 \%$ \\
\hline Flemish Region & 215693 & 181763 & $-1 \%$ \\
\hline Walloon Region & 98705 & 90720 & $+8 \%$ \\
\hline Belgium & 554744 & 470263 & $+/-0 \%$ \\
\hline Flemish periphery around Brussels & 70482 & 58932 & $-1 \%$ \\
\hline Urban agglomeration of Brussels & 310143 & 235281 & $-11 \%$ \\
\hline Urban agglomeration of Brussels - Flemish & 59544 & 49833 & $-1 \%$ \\
\hline Urban agglomeration of Brussels - Walloon & 10253 & 8668 & $-0 \%$ \\
\hline Suburban area of Brussels & 49434 & 43123 & $+3 \%$ \\
\hline Suburban area Brussels - Flemish & 26944 & 22749 & $-0 \%$ \\
\hline Suburban area Brussels - Walloon & 22490 & 20374 & $+7 \%$ \\
\hline Commuter area of Brussels & 72392 & 63908 & $+4 \%$ \\
\hline Commuter area of Brussels - Flemish & 50858 & 42601 & $-1 \%$ \\
\hline Commuter area of Brussels - Walloon & 21534 & 21307 & $+17 \%$ \\
\hline
\end{tabular}

Table 4. Evolution of the price of construction land in BCR and its surroundings $\left(€ / \mathrm{m}^{2}\right)$

\begin{tabular}{|c|c|c|c|c|c|}
\hline & 1990 & 1995 & 2010 & 1990-1995 & $1995-2010$ \\
\hline Brussels-Capital Region & 125.7 & 112.6 & 374.6 & $-10 \%$ & $+233 \%$ \\
\hline Flemish Region & 23.2 & 32.0 & 155.3 & $+38 \%$ & $+385 \%$ \\
\hline Walloon Region & 13.4 & 15.4 & 46.9 & $+15 \%$ & $+205 \%$ \\
\hline Belgium & 22.6 & 26.9 & 102.8 & $+19 \%$ & $+283 \%$ \\
\hline Flemish periphery around Brussels & 47.0 & 60.9 & 233.7 & $+30 \%$ & $+284 \%$ \\
\hline Urban agglomeration of Brussels & 52.5 & 65.1 & 244.4 & $+24 \%$ & $+275 \%$ \\
\hline Urban agglomeration of Brussels - Flemish & 50.6 & 64.0 & 242.6 & $+26 \%$ & $+279 \%$ \\
\hline Urban agglomeration of Brussels - Walloon & 30.0 & 49.9 & 191.2 & $+67 \%$ & $+283 \%$ \\
\hline Suburban area of Brussels & 23.7 & 35.2 & 160.3 & $+49 \%$ & $+355 \%$ \\
\hline
\end{tabular}




\begin{tabular}{|c|r|r|r|r|r|}
\hline Suburban area Brussels - Flemish & 27.3 & 41.3 & 205.9 & $+52 \%$ & $+398 \%$ \\
\hline Suburban area Brussels - Walloon & 20.1 & 29.1 & 110.9 & $+45 \%$ & $+281 \%$ \\
\hline Commuter area of Brussels & 16.0 & 23.3 & 112.7 & $+46 \%$ & $+383 \%$ \\
\hline Commuter area of Brussels - Flemish & 19.3 & 28.0 & 156.2 & $+45 \%$ & $+459 \%$ \\
\hline Commuter area of Brussels - Walloon & 12.2 & 18.0 & 65.9 & $+27 \%$ & $+265 \%$ \\
\hline
\end{tabular}

Table 5. Evolution of the price of an average house in BCR and its surroundings ( $€$ )

\begin{tabular}{|l|r|r|r|r|r|}
\hline & \multicolumn{1}{|l|}{1990} & \multicolumn{1}{|l|}{1995} & \multicolumn{1}{l|}{2010} & $1990-1995$ & $1995-2010$ \\
\hline Brussels-Capital Region & 75517 & 98165 & 336207 & $+30 \%$ & $+242 \%$ \\
\hline Flemish Region & 47777 & 67217 & 192336 & $+41 \%$ & $+186 \%$ \\
\hline Walloon Region & 37795 & 52391 & 139615 & $+39 \%$ & $+166 \%$ \\
\hline Belgium & 45441 & 62954 & 180930 & $+39 \%$ & $+187 \%$ \\
\hline Flemish periphery around Brussels & 69965 & 97876 & 260667 & $+40 \%$ & $+166 \%$ \\
\hline Urban agglomeration of Brussels & 69831 & 97168 & 263541 & $+39 \%$ & $+171 \%$ \\
\hline Urban agglomeration of Brussels - Flemish & 69157 & 96848 & 259695 & $+40 \%$ & $+168 \%$ \\
\hline Urban agglomeration of Brussels - Walloon & 72046 & 99067 & 256057 & $+38 \%$ & $+158 \%$ \\
\hline Suburban area of Brussels & 65531 & 91686 & 241274 & $+40 \%$ & $+163 \%$ \\
\hline Suburban area Brussels - Flemish & 65602 & 93657 & 241268 & $+43 \%$ & $+158 \%$ \\
\hline Suburban area Brussels - Walloon & 65459 & 89714 & 241281 & $+37 \%$ & $+169 \%$ \\
\hline Commuter area of Brussels & 48883 & 69611 & 183115 & $+42 \%$ & $+163 \%$ \\
\hline Commuter area of Brussels - Flemish & 48523 & 69524 & 184453 & $+43 \%$ & $+165 \%$ \\
\hline Commuter area of Brussels - Walloon & 49295 & 69710 & 181586 & $+41 \%$ & $+160 \%$ \\
\hline
\end{tabular}

From a planning perspective, we may evaluate the demonstrated urban compaction of Brussels as positive, since this reflects the goals of a compact-city policy.

However, the associated peri-urbanization in the Walloon municipalities has many negative consequences, including mobility issues which are described in Dujardin et al. (2012). A controlled process of suburban development in the Flemish periphery around Brussels would possibly have led to a more compact agglomeration, with positive effects on the organization of the area (e.g. in terms of transport).

\section{Expected impact of the UGB around BCR}

Inside the UGB for the part of the Brussels agglomeration that is located in the Flemish periphery, originally additional development space for 6,000 new homes was provided, which is equivalent to about 14,400 inhabitants. The document that talks of 6,000 additional homes is a research report from 2008 that was not included in the final public review process. In this report the demand for housing up to 2007 was estimated at more than 17,000 dwellings, out of which 11,000 could be built on vacant lots on existing construction land (Omgeving et al., 2008, p. 197). Since the proposal of UGB does not impose clear conditions on the development of housing 
outside the demarcation line, we may assume that another $46 \%$ of the additional homes that will be built in the concerned municipalities will be situated outside the UGB.

The plans that eventually have been adopted, did no longer contain quantitative targets for additional dwellings (VSGB, 2009, p. 25). Moreover, no planning horizon was defined. The absence of these two elements raises the question whether this is really an UGB in the strict sense of the term.

The plan focuses strongly on protection of the open space (both inside and immediately outside the demarcation line) and on discouraging the construction of apartment blocks and high-rise buildings. Furthermore, additional business estates are designated, apart from additional residential construction land which is rather limited, while parts of the formerly existing not yet built-up residential expansion land (in less well-located sites) are turned into protected open space. Although no formal targets are attached to this plan, in practice it is still based on the demand for housing as it was estimated for 2007 (6,000 dwellings), a goal which is combined with relatively low density targets that are for most areas prescribed at about 25 dwellings per hectare. Finally, of course, the plan also contains a demarcation line, making it formally fit in the range of UGB's as put up for the smaller cities in Flanders.

In Table 6, we have presented transaction data for construction land, as a proxy of the amount of available vacant lots. The fact that the supply of construction land in the Walloon commuter area is only slowly dwindling (-27\% over the period 19952010), while the fastest decline is observed in the Flemish periphery around Brussels ( $-55 \%$ over the same period), indicates that peri-urbanization (towards remote locations from Brussels), particularly in Wallonia, is partly fuelled by the supply of available construction land. In BCR, in contrast, the necessary housing supply that facilitates population growth is almost exclusively created by renovation and infill development, in particular by replacing single-family houses and former industrial buildings by apartment blocks (Dessouroux and Romainville, 2011). Market forces regarding the price of construction land are at least a partial explanation for the observed growth in the peri-urban municipalities, while this seems hardly the case in the urban agglomeration. This is shown in Table 7. This simple correlation analysis 
of the prices of construction land with the evolution of the population, aggregated by municipality, teaches us that construction land prices in the suburban area and the commuter area are negatively correlated with the evolution of the population, while this is not the case in the urban agglomeration. This means that lower prices in the periphery (e.g. because of an increased supply) would lead to a much faster population growth than is the case today (or than would be the case in the suburban and commuter area when prices would fall there), since it is exactly here that population growth is already high under current, high, price levels.

Table 6. Evolution of the number of construction land transactions in BCR and its surroundings

\begin{tabular}{|c|c|c|c|c|c|}
\hline & 1990 & 1995 & 2010 & $1990-1995$ & $1995-2010$ \\
\hline Brussels-Capital Region & 783 & 269 & 252 & $-25 \%$ & $-39 \%$ \\
\hline Flemish Region & 30177 & 22100 & 12470 & $-27 \%$ & $-44 \%$ \\
\hline Walloon Region & 11841 & 9631 & 6956 & $-19 \%$ & $-28 \%$ \\
\hline Belgium & 42801 & 32000 & 19678 & $-25 \%$ & $-39 \%$ \\
\hline Flemish periphery around Brussels & 2054 & 1178 & 490 & $-43 \%$ & $-58 \%$ \\
\hline Urban agglomeration of Brussels & 2768 & 1389 & 786 & $-50 \%$ & $-43 \%$ \\
\hline Urban agglomeration of Brussels - Flemish & 1673 & 940 & 424 & $-44 \%$ & $-55 \%$ \\
\hline Urban agglomeration of Brussels - Walloon & 312 & 180 & 110 & $-42 \%$ & $-39 \%$ \\
\hline Suburban area of Brussels & 2223 & 1404 & 687 & $-37 \%$ & $-51 \%$ \\
\hline Suburban area Brussels - Flemish & 1061 & 744 & 340 & $-30 \%$ & $-54 \%$ \\
\hline Suburban area Brussels - Walloon & 1162 & 660 & 347 & $-43 \%$ & $-47 \%$ \\
\hline Commuter area of Brussels & 4025 & 3096 & 1979 & $-23 \%$ & $-36 \%$ \\
\hline Commuter area of Brussels - Flemish & 2591 & 2111 & 1259 & $-19 \%$ & $-40 \%$ \\
\hline Commuter area of Brussels - Walloon & 1434 & 985 & 720 & $-31 \%$ & $-27 \%$ \\
\hline
\end{tabular}

Table 7. Correlation between construction land price (in 1990 and in 2010) and population change (1995-2010), by urban category

\begin{tabular}{|l|r|r|}
\hline & correlation coefficient & p-value and significance \\
\hline urban agglomeration - land price: 1990 & -0.24 & 0.34 n.s. \\
\hline urban agglomeration - land price: 2010 & -0.18 & 0.50 n.s. \\
\hline suburban area - land price: 1990 & -0.48 & $0.01 * *$ \\
\hline suburban area - land price: 2010 & -0.42 & $0.04 * *$ \\
\hline commuter area - land price: 1990 & -0.33 & $0.01 * *$ \\
\hline commuter area - land price: 2010 & -0.50 & $0.00 * *$ \\
\hline
\end{tabular}

$$
\text { ** significant at the } 0.05 \text {-level n.s.: not significant }
$$

These elements suggest that the UGB containing the Flemish periphery around Brussels will continue to consolidate the disproportionately low growth rate that 
exists today in this region, with important consequences for the spatial structure and the property markets of both BCR and the areas in the Walloon and the Flemish Region that are further away from Brussels. In BCR, we may expect further densification, while prices of the existing properties in the Flemish periphery will continue to rise rapidly. Because of the language issue, a disproportionally large part of the spillover of BCR, for which no space has been foreseen within the UGB, will direct to the suburban and the commuter areas in (French-speaking) Wallonia, inducing even more long-distance commuting to Brussels (Boussauw et al., 2012). Another portion of this spillover will end up in Flanders, with a similar, albeit less important, effect on the commuter flows. The growth of these municipalities situated further away from Brussels is a phenomenon very similar to what was found in Portland, where a significant portion of the growth ended up in the neighbouring towns where no UGB regulations applied (Jun, 2004).

\section{Conclusion}

In Flanders, the demarcation of the urban areas originally intended to implement urban development programmes, including the allocation of the majority of additional dwellings, and to safeguard the open space outside the urban areas. Nevertheless, in the Flemish periphery around Brussels the application of this planning instrument seems not to lead to organized compact development. The main achievement of the planning process that has led to the delineation of the Flemish periphery around Brussels is that the growth in the number of families in this area is curbed. Nevertheless, it can be expected that growth in BCR itself will continue unabatedly, with further densification within the administrative border (which is considerably narrower than the UGB) as a result. On the other hand, the commuter areas that are located further away, especially those situated in French-speaking Wallonia, will receive part of the growth of BCR. Densification of BCR responds to a compact-city policy, and therefore has some advantages in terms of mobility and economical use of land, energy and facilities. However, the growth of the commuter municipalities that are located further away will result in increasing periurbanization, which is, in contrast, associated with less efficient use of land, energy and facilities. Another important consequence is that commuter traffic will also 
grow, which is expected to result in greater environmental burden and increasing road (and rail) capacity problems.

In this case, the geographical distribution and the interests of the various language groups in Belgium interfere strongly with regional and urban planning policies, implying that the actual UGB around Brussels coincides in reality with the administrative border of BCR, and thus not with the Flemish demarcation. Since this administrative border is perhaps much tighter than a judiciously defined UGB would be, this leads on the one hand to excessive compaction of BCR, and on the other hand to a spillover effect resulting in an only loosely controlled form of periurbanization in municipalities that are rather distant from the Brussels agglomeration. 


\section{References}

ALBRECHTS, L. (1999) Planners as catalysts and initiators of change. The new Structure Plan for Flanders, European Planning Studies, 7, pp. 587-603.

ALBRECHTS, L., HEALEY, P. and KUNZMANN, K. R. (2003) Strategic spatial planning and regional governance in Europe, Journal of the American Planning Association, 69, pp. 113-129.

ARC (2011) PLAN 2040. Atlanta: Atlanta Regional Commission.

BOUSSAUW, K., NEUTENS, T. and WITLOX, F. (2011) Minimum commuting distance as a spatial characteristic in a non-monocentric urban system: The case of Flanders, Papers in Regional Science, 90, pp. 47-65.

BOUSSAUW, K., NEUTENS, T. and WITLOX, F. (2012) Relationship between spatial proximity and travel-to-work distance: The effect of the compact city, Regional Studies, 46, pp. 687-706..

BRUECKNER, J. K. (2000) Urban sprawl: Diagnosis and remedies, International Regional Science Review, 23, pp. 160-171.

BRUECKNER, J. K. (2007) Urban growth boundaries: An effective second-best remedy for unpriced traffic congestion? Journal of Housing Economics, 16, pp. 263-273.

BURBY, R. J., NELSON, A. C., PARKER, D. and HANDMER J. (2001) Urban containment policy and exposure to natural hazards: Is there a connection? Journal of Environmental Planning and Management, 44, pp. 475-490. 
DAWKINS, C. J. and NELSON, A. C. (2002) Urban containment policies and housing prices: An international comparison with implications for future research, Land Use Policy, 19, pp. 1-12.

DE DECKER, P. (2011) Understanding housing sprawl: the case of Flanders, Belgium, Environment and Planning A, 43, pp. 1634-1654.

DE MAESSCHALCK, F. (2011) The politicisation of suburbanisation in Belgium: Towards an urban-suburban divide, Urban Studies, 48, pp. 699-717.

DESCHOUWER, K. (2006) And the peace goes on? Consociational democracy and Belgian politics in the twenty-first century, West European Politics, 26, pp. 895911.

DESSOUROUX, C. and ROMAINVILLE, A. (2011) La production de logements en Belgique et à Bruxelles - Acteurs, dynamiques, géographie, EchoGéo, 15, pp. 1-19.

DICKINSON, R. E. (1957) The geography of commuting: The Netherlands and Belgium, Geographical Review, 47, pp. 521-538.

DING, C., KNAAP, G. J. and HOPKINS, L. D. (1999) Managing urban growth with urban growth boundaries: A theoretical analysis, Journal of Urban Economics, 46, pp. 53-68.

DUJARDIN, S., BOUSSAUW, K., BRÉVERS, F., LAMBOTTE, J.-M., TELLER, J. and WITLOX F. (2012) Sustainability and change in the institutionalized commute in Belgium: Exploring regional differences, Applied Geography, 35, pp. 95-103.

GENNAIO, M.-P., HERSPERGER, A. M. and BÜRGI, M. (2009) Containing urban sprawl - Evaluating effectiveness of urban growth boundaries set by the Swiss Land Use Plan, Land Use Policy, 26, pp. 224-232. 


\section{GEWOP/PRD (2002) Gewestelijk Ontwikkelingsplan / Plan Régional de}

Développement. Brussels: Brussels-Capital Region.

JANSSENS, R. (2007) Van Brussel gesproken: Taalgebruik, taalverschuivingen en taalidentiteit in het Brussels Hoofdstedelijk Gewest (Taalbarometer II). Brussels: Academic and Scientific Publishers - VUBPress.

JUN, M.-J. (2004) The effects of Portland's urban growth boundary on urban development patterns and commuting, Urban Studies, 41, pp. 1333-1348.

JUN, M.-J. (2006) The effects of Portland's urban growth boundary on housing prices, Journal of the American Planning Association, 72, pp. 239-243.

KNAAP, G. J. (1985) The price effects of urban growth boundaries in metropolitan Portland, Oregon, Land Economics, 61, pp. 26-35.

KNAAP, G. J. and HOPKINS, L. D. (2001) The inventory approach to urban growth boundaries, Journal of the American Planning Association, 67, pp. 314-326.

LAMBERT, A. and LOHLÉ-TART, L. (2010) Combien de Bruxellois flamands aujourd'hui et demain dans la région de Bruxelles-Capitale? Brussels: Adrass asbl.

LEINFELDER, H. and ALLAERT, G. (2010) Increasing societal discomfort about a dominant restrictive planning discourse on open space in Flanders, Belgium, European Planning Studies, 18, pp. 1787-1804.

LEPERS, E. and MORELLE, D. (2008) Occupation et affectation du sol, empreintes de la structure du territoire? Territoire(s) Wallon(s), 3, pp. 43-58.

LUYTEN, S. and VAN HECKE, E. (2007) De Belgische Stadsgewesten 2001. Brussels: Statistics Belgium. 
MARCHAND, B. and CAVIN, J. S. (2007) Anti-urban ideologies and planning in France and Switzerland: Jean-François Gravier and Armin Meili, Planning Perspectives, 22, pp. 29-53.

MEERT, H. (1993) Sociale verdringing en huisvestingsbeleid in Vlaams-Brabant, in: E. WITTE (Ed) Brusselse Thema's 1: De Brusselse Rand, Brussels: VUBPress.

MILLWARD, H. (2006) Urban containment strategies: A case-study appraisal of plans and policies in Japanese, British, and Canadian cities, Land Use Policy, 23, pp. 473-485.

NELSON, A. C., DAWKINS, C. J. and SANCHEZ, T. W. (2004) Urban containment and residential segregation: A preliminary investigation, Urban Studies, 41, pp. 423-439.

O’NEILL, K. M., RUDEL, T. K. and MCDERMOTT, M. H. (2011) Why environmentally constrained towns choose growth controls, City \& Community, 10, pp. 111-130.

OMGEVING, ARCADIS, IDEA CONSULT, TRITEL and O2 CONSULT (2008) Overlegproces Vlaams Stedelijk Gebied rond Brussel - Eindrapport. Brussels: Ministry of the Flemish Community.

OOSTERLYNCK, S. (2010) Regulating regional uneven development and the politics of reconfiguring Belgian state space, Antipode, 42, pp. 1151-1179.

OXLEY, M., BROWN, T., NADIN, V., QU, L., TUMMERS, L. and FERNÁNDEZMALDONADO, A. M. (2009) Review of European Planning Systems. Leicester: Centre for Comparative Housing Research - De Montfort University. 
PRIEMUS, H. (1998) Contradictions between Dutch housing policy and spatial planning, Tijdschrift voor Economische en Sociale Geografie. 89, pp. 31-43.

RODRIGUEZ, D. A., TARGA, F. and AYTUR, S. A. (2006) Transport implications of urban containment policies: A study of the largest twenty-five US metropolitan areas, Urban Studies, 43, pp. 1879-1897.

RSV (1997) Ruimtelijk Structuurplan Vlaanderen. Brussels: Ministry of the Flemish Community.

RSV (2004) Ruimtelijk Structuurplan Vlaanderen - Gecoördineerde Versie. Brussels: Ministry of the Flemish Community.

SCHEERS, J. (2006) Spatial planning in the economic core of Europe: The transition from land use planning to spatial structure planning in Flanders, in: N. ADAMS, ALDEN, J. and HARRIS, N. (Eds) Regional Development and Spatial Planning in an Enlarged European Union, Aldershot: Ashgate.

SONG, Y. and KNAAP, G.-J. (2004) Measuring urban form - Is Portland winning the war on sprawl? Journal of the American Planning Association, 70, pp. 210225.

STATISTICS BELGIUM (2011a) Bevolking - Cijfers bevolking 1990-2010 from http://economie.fgov.be/nl/modules/publications/statistiques/bevolking/cijfers_bevol king_1_1_2009.jsp.

STATISTICS BELGIUM (2011b) Algemene socio-economische enquête 2001 from http://statbel.fgov.be/nl/statistieken/cijfers/bevolking/volkstelling/2001/.

STATISTICS BELGIUM (2011c) Vastgoedprijzen from

http://statbel.fgov.be/nl/statistieken/cijfers/economie/bouw_industrie/vastgoed/. 
VALASEK, M. (1990) The 'other language': Language planning in Belgium, Penn Working Papers in Educational Linguistics, 6, pp. 85-107.

VAN CRIEKINGEN, M. (2008) Towards a geography of displacement. Moving out of Brussels' gentrifying neighbourhoods, Journal of Housing and the Built Environment, 23, pp. 199-213.

VANDERMOTTEN, C., ROELANDTS, M., AUJEAN, L. and CASTIAU, E. (2006) Central Belgium: Polycentrism in a federal context, in: P. HALL and PAIN, K. (Eds) The Polycentric Metropolis: Learning from Mega-City Regions in Europe, London: Earthscan.

VAN NUFFEL, N. (2005) Regionalisering van de woonmarkt. Een onderzoek naar de ruimtelijke structurering van het nederzettingspatroon in Noord-België. PhD thesis. Ghent: Ghent University.

VOETS, J., DE PEUTER, B., VANDEKERCKHOVE, B., BROECKAERT, D., LE ROY, M., MAES, P., DE DECKER, P., BERVOETS, W., VAN DER HEIJDEN, R.and BLUMMEL, P. (2010) Evaluerend onderzoek naar de effectiviteit van de uitvoering van het ruimtelijk beleid in Vlaanderen. Brussels: Ministry of the Flemish Community.

VSGB (2009) Ontwerp van Gewestelijk Ruimtelijk Uitvoeringsplan Afbakening van het VSGB en Aansluitende Open-Ruimtegebieden. Brussels: Ministry of the Flemish Community.

WEITZ, J. and MOORE, T. (1998) Development inside urban growth boundaries: Oregon's empirical evidence of contiguous urban form, Journal of the American Planning Association, 64, pp. 424-440.

WILLEMYNS, R. (2002) The Dutch-French language border in Belgium, Journal of Multilingual and Multicultural Development, 23, pp. 36-49. 
ZONNEVELD, W. (2005) The Europeanization of Dutch national spatial planning: An uphill battle, disP - The Planning Review, 41, pp. 4-15. 